Published in Tourism Management, 2019, vol. 70, pp. 78-88, which should be cited to refer to this work.

DOI : $10.1016 / j . t o u r m a n .2018 .04 .003$

\title{
What is happening in Paris? Airbnb, hotels, and the Parisian market: A case study
}

3

Cindy Yoonjoung $\mathrm{Heo}^{\mathrm{a}}$, Inès Blal ${ }^{\mathrm{a}}$, Miju Choi ${ }^{\mathrm{b}}$

4

5

6

8

9 Switzerland

\section{Keywords} rental; Paris

To cite this article: and Parisian. Tourism Management, 70, 78-88.

DOI: https://doi.org/10.1016/j.tourman.2018.04.003

${ }^{a}$ Ecole hôtelière de Lausanne, HES-SO/University of Applied Sciences Western Switzerland,

${ }^{\mathrm{b}}$ School of Events, Tourism \& Hospitality Management, Leeds Beckett University, UK

\begin{abstract}
Airbnb has been the subject of heated discussions among tourism and hospitality scholars. In order to understand the true impact of P2Psharing on the tourism and hospitality landscape, it is important to understand that market in detail first. Therefore, in this paper, we explore the development of the Airbnb market over the last seven years in Paris, the most popular destination for Airbnb guests with more than 40,000 accommodation rentals. This research note is a summary of our findings on the Paris market. Our study shows different growth and seasonality patterns for Airbnb and hotels and dissimilarities in the geographical location of the offers. The findings indicate that the two products are not in direct competition and that their relationship might be more complex than previously thought. We trust that exploring the nature of the competitive relationship would be a valuable avenue for further investigation.
\end{abstract}

Sharing economy; P2P sharing; Collaborative consumption; Airbnb; P2P accommodation

Cindy Yoonjoung Heo, Inès Blal, Miju Choi (2019). What is happening in Paris? Airbnb, hotels, 


\section{Introduction}

Airbnb has been the subject of numerous and often heated discussions among hoteliers and academics in the industry. The original "Airbed and Breakfast" offer of two students in San Francisco, abbreviated AirBnb since, is a platform that allows people to look for, rent and/or list properties for accommodation. While official revenues have not been disclosed, Fortune magazine reports that Airbnb's annual revenues are expected to reach $\$ 10$ billion by 2020. Despite this meteoric growth, major hotel chains have yet to show substantial action to withstand the potential competition from the sharing economy. Steve Joyce, the chief executive of Choice Hotels International, mentioned that his brands had not seen any effect from Airbnb. Equally, Kerry Ranson, chairman of the InterContinental Hotels Group Owners Association, said that he did not see Airbnb as a threat or a competitor (Weed, 2015). Hilton CEO Chris Nassetta expressed a similar view, saying that Airbnb was not a major threat to his company's business and the effect of Airbnb is heterogeneous across hotel markets (Bryan, 2015).

However, HVS analysts reported that the overall impact of Airbnb's operations in New York City is estimated to be \$2.1 billion over the twelve-month period from September 2014 through August 2015. Further, the report concluded that Airbnb has eliminated more than 2,800 jobs and resulted in more than $\$ 226$ million annually in lost tax revenues for local, state, and federal governments. And recent research appears to substantiate these findings. Zervas, Proservio, and Byers (2017) measured that a 1\% increase in Airbnb listings causes a $.05 \%$ decrease in hotel revenues in the U.S. state of Texas. But according to STR research, Airbnb did not have a measurable effect on hotel demand in Manhattan. Similarly, analysts at Deutsche Bank noted that in many major cities, hotel revenue per available room was maintained while the supply of rooms including Airbnb listings has increased significantly 
(Bryan, 2015). Their view is that Airbnb is not a risk for hotels. To the contrary, they see such businesses growing the market by creating new demand. These analysts draw the parallel between the sharing economy in the hotel industry and the low-cost airlines in the air transportation sector. Low-cost airlines such as EasyJet or Ryanair expanded the travel market and provided opportunities for those who would otherwise not have been able to travel, or would have travelled less frequently otherwise.

In line with this viewpoint, Airbnb claims that its offer has had positive economic impact. In France, for instance its executives report that its visitors contribute significantly to France's tourism industry, local businesses and local households (Airbnb, 2015). According to an Airbnb report, the company has contributed to the increase in tourism in France. Indeed, they report that $23 \%$ of Airbnb guests said they would not have gone on their trip or would not have stayed as long without Airbnb. Also, $66 \%$ of Airbnb guests said they would not have stayed in a hotel even if Airbnb had not been an option. We therefore have contradictory opinions and stands on the effects of Airbnb on the hotel business.

As the rise of $\mathrm{P} 2 \mathrm{P}$ sharing services changed the way people travel, it is not only changing competitive landscape in the hotel industry, but also transforming the tourism industry. This new trend has blurred the boundaries between consumers and service providers as well as local residents and business entities in the tourism destination (Heo, 2016). Further, Airbnb claims that it gave some tourism destinations the chance to diversify beyond typical tourist hot spots. As the P2P business develops, it seems timely to conduct empirical investigation and explore in more depth the phenomenon. Hotel and Airbnb may not be completely comparable from a supplier's perspective, because the nature and size of business is dissimilar. However, from a demand perspective, it is important to compare hotel and Airbnb in order to understand the changing landscape of tourism and hospitality, because consumers regard Airbnb as an alternative to hotel. 


\section{Previous literature}

This boom of Airbnb, and by in large in the sharing economy, has attracted attention

from academics and researchers in the tourism and hospitality industry. They have started exploring various aspects pertaining to the Peer-to-Peer (P2P) accommodation rental services such as Airbnb. Guttentag (2015), for instance, discussed Airbnb from a disruptive innovation theory perspective. According to this view, products that lack in traditionally preferred attributes but offer alternative benefits can transform a market and capture mainstream consumers over time. Several researchers (e.g., Tussyadiah, 2015) worked on identifying the characteristics of the P2P sharing transactions and its implications. Cheng (2016), for instance, highlighted that the sharing economy empowers people's mobility and encourages traditional tourism service providers to innovate and redefine their business models. Previous research also suggests that the sharing economy has incrementally allowed tourists to have a wide range of products and services at a more reasonable price (e.g., Shaheen, Mallery, \& Kingsley, 2012), helped authentic encounters between tourists and locals (e.g., Molz, 2013; Tussyadiah \& Pesonen, 2016) and contributed to the employment and income of locals (e.g., Fang, Ye, \& Law, 2016). Gutiérrez, et al. (2017) argued that Airbnb expands the tourism pressure over residential areas in the centre.

In addition, several research explored various factors influencing participants' decision. For example, Liang, et al (2017) found that accommodations rewarded with the "Superhost" badge are more likely to receive reviews and higher ratings and guests are willing to pay more for "Superhost" accommodations. Ert, Fleischer, and Magen (2017)'s study found the importance of trust and reputation on guests' decisions by highlighting the role of personal photo in Airbnb. Their study found that a more trustworthy photo leads to a higher price and increased chance to purchase. According to Poon and Huang (2017)'s study, Airbnb is found 
to be more appealing to people who are allocentric, and when travelling alone, with spouse/partner, and with friends, particularly for longer trips. Others have conducted research from a host's perspective, mostly focusing on pricing issues. For example, Edelman, Luca and Svirsky (2017) found that non-black Airbnb hosts charge approximately $12 \%$ more than black hosts for a comparable accommodation in New York City.Wang and Nicolau (2017) found that Airbnb hosts with super host status, more listings, and verified identities usually charge higher prices. Similarly, Gibbs et al. (2017) found physical characteristics, location, and host characteristics significantly impact Airbnb accommodation rates in five metropolitan areas in Canada.

Although several studies have explored various topics on P2P platforms for accommodation sharing, few research focused on how P2P accommodation rental services have changed the tourism landscape. In order to understand the true impact of $\mathrm{P} 2 \mathrm{P}$ sharing on tourism and hospitality, it is important to understand that market in detail first. Zervas, et al. (2017) tried to estimate the impact of Airbnb on the hotel industry, but their study did not consider seasonality and different locations. Therefore, the next section explors the trends in the Parisian market, the most popular destination for Airbnb guests with more than 40,000 accommodation rentals, by comparing their performers by month and by different locations.

\section{The Parisian market}

Paris is a key destination for Airbnb, where its growth has exploded over the past five year. Airbnb (2015) reported that one third of its guests visit Paris. Moreover, direct Airbnb guest spending in Paris, excluding accommodation, amounted to 980 million euros. As for the income earned by Paris hosts from Airbnb rentals, it reached 213 million euros. But hoteliers in the French capital denounce Airbnb as a menace that enjoys an unfair advantage. Since P2P accommodation rentals, such as Airbnb, have become an increasingly professional operation, French hoteliers are demanding new regulations. For example, in France, the Union of Hotel 
Industry Trades (UMIH) argued that P2P accommodation rentals are no longer part of the sharing economy and should be taxed and regulated in the same way hotels are. However, Airbnb defends the social aspect of its business, and claims that most Airbnb hosts are longtime Paris residents who predominately share the home they live in. They report that Parisian hosts have, on average, lived in Paris for 19 years and 93\% of Paris hosts have only one listing.

In Paris, about 60,000 rentals are currently offered via P2P accommodation sharing platforms like Airbnb (Radio Bleu). A recent change in legislation allows French citizens the right to rent their main residence for four months in a year. As a result, in 2015, tourist tax revenue collected from hosts and paid to the city of Paris amounted to $€ 1.2$ million in the first three months of operation (Lomas, 2016). In a trend to accommodate the changes introduced by P2P rental platforms, new governmental structures also emerged. In May 2016, for instance, Paris officials created a new section of the city's open data portal that lists residents who have registered as an Airbnb host. Through this portal, residents can report on their annoying neighbour and those hosts who are not playing by the rules. Furthermore, under the new legislation, if a person rents a place through a P2P accommodation platform without being a registered host, she incurs a fine of up to $€ 25,000$ (USD 28,000). But while there are more than 41,000 listings in Paris on the Airbnb website, only 126 places of residence are listed as Airbnb sites on the city's website as of May 2016. A Guardian investigation discovered that more than $30 \%$ of primary homes in Paris were rented out for more than 120 days a year and more than $40 \%$ of properties were commercial listings. According to statistics from the Association for Accommodation and tourism professionals (Ahtop: L'Association pour un Hébergement et un Tourisme Professionnels), an estimated 15,000 to 20,000 of accommodations are rented out illegally. Further, Airbnb has been blamed for a marked reduction in the population of Paris. According to research published in French daily Le 
Parisien, the number of people living in Paris between 2009 and 2014 fell from 2,234,105 to 2,220,445. Jean-François Legaret, mayor of the 1st district, said that "The drop in population can be attributed to the Airbnb phenomenon which has been a catastrophe for central Paris," during the interview with Le Parisien.

Paris, the capital and most populous city of France and Europe's main tourist capital, has become a flash point where Airbnb's prosperity, hotelier's anxiety, and local residents' anger collide today. Therefore, in this paper, we explore the development of the Airbnb market over the last seven years in Paris and analyze its relationship with the hotel business in the capital. Also this study examines the market exhaustively by comparing their performers by month and by different administration district in Paris.

\section{Data and methodology}

To conduct our analysis, we used data from the Paris Convention and Visitors Bureau and Airdna. From the annual reports of the Paris Convention and Visitors Bureau we collected hotel-related performance (e.g., total supply, monthly ADR, monthly occupancy, monthly revenues, revenues and occupancy by Parisian district). This information was available only between 2010 and 2014 as the format of the annual report is different for 2015 . We completed the 2015 data with PWC reports available on the Statista website. We would like to note here, that while the data on occupancy rates were the same in the PWC and the annual reports of the Paris Visitors bureau, the ADR was different. For the sake of consistency, we used the ADR from the Visitor's bureau. Airdna supplied data pertaining to Airbnb's activities for the 2009-2015 period including: property IDs, type of property, number of bookings per listing, property average daily rate, property occupancy, property revenues. Airdna considers a rental listing to be active if it has been posted in the last 60 days or had a reservation in the last 30 days. 
Three types of accommodations are available on Airbnb: shared room, private room, and entire house/apartment. We calculated the total number of Airbnb rooms by combining the number of private rooms and entire houses. In other words, we excluded the shared room from our computation as we don't perceive this type of accommodation as being a direct competition for a hotel room. Within the same approach, although an entire house may have three bedrooms, we counted all entire houses/apartments as one room because bookings are typically made for an entire house rather than individual bedrooms.

Our purpose in this research note is to explore the relationship between Airbnb and hotel supply and demand in the Parisian market. Thus, we focused on contrasting patterns and testing possible interactions. In particular, we conducted time series analysis on monthly hotel and Airbnb ADR and occupancy to empirically investigate the patterns that emerged from the data. Furthermore, we tested the effects of Airbnb total revenues, average ADR and bookings on hotels' total revenues and ADR in linear regression models.

\section{Research findings}

\subsection{A five-year plateau for hosts' profitability?}

Table 1 presents a general overview of Airbnb in Paris. In particular, it includes, for the supply data, the number of Airbnb property IDs (i.e. total listings on the platform during a given year), total number of hosts registered, and the total number of Airbnb's private units on the market. In terms of demand, Table 1 presents: average annual ADRs, occupancy rate, average and total number of booking, and total revenues. The supply data presents a predictable pattern: the number of listings has surged since the opening of the platform on the Parisian market with an average annual growth rate of $230 \%$ for listings, $226 \%$ for the number of private units, and $211 \%$ for the number of hosts offering rentals on the platform. 
Table 1. The overview of Airbnb listings in Paris (2009 -2015)

\begin{tabular}{cccc}
\hline Variable & Intercept & Trend & R2 \\
\hline AirBnb & $138.91(\mathrm{P}=0.00)$ & $-0.18(\mathrm{P}=0,07)$ & 0.04 \\
Hotel AvgADR & $136.63(\mathrm{P}=0.00)$ & $0.63(\mathrm{P}=0.00)$ & 0.26 \\
\hline
\end{tabular}

AIRBNB SUPPLY

AIRBNB DEMAND

\begin{tabular}{cccccccccc}
\hline Listings & $\begin{array}{c}\text { Total } \\
\text { Private } \\
\text { Units }\end{array}$ & $\begin{array}{c}\text { Total } \\
\text { Hosts }\end{array}$ & $\begin{array}{c}\text { Average } \\
\text { ADR* }\end{array}$ & $\begin{array}{c}\text { Average } \\
\text { Occ. } \\
\text { Rate }\end{array}$ & $\begin{array}{c}\text { Average } \\
\text { number } \\
\text { of } \\
\text { bookings }\end{array}$ & $\begin{array}{c}\text { Average } \\
\text { revenue* }\end{array}$ & $\begin{array}{c}\text { Total } \\
\text { bookings }\end{array}$ & $\begin{array}{c}\text { Total } \\
\text { Revenue* }\end{array}$ \\
\hline 2009 & 66 & 88 & 66 & 140.70 & $51 \%$ & 15 & 11,022 & 990 & 727,452 \\
\hline 2010 & 354 & 440 & 354 & 132.66 & $56 \%$ & 16 & 12,226 & 5,664 & $4,328,004$ \\
\hline 2011 & 1,122 & 1,399 & 1,122 & 128.29 & $55 \%$ & 15 & 11,833 & 16,830 & $13,276,626$ \\
\hline 2012 & 4,296 & 5,543 & 4,292 & 126.89 & $55 \%$ & 13 & 10,127 & 55,848 & $43,505,592$ \\
\hline 2013 & 9,536 & 12,208 & 9,520 & 125.42 & $53 \%$ & 11 & 9,153 & 104,896 & $87,283,008$ \\
\hline 2014 & 18,894 & 23,772 & 18,858 & 121.05 & $53 \%$ & 10 & 8,174 & 188,940 & $154,439,556$ \\
\hline 2015 & 39,608 & 48,748 & 39,415 & 132.14 & $49 \%$ & 7 & 5,543 & 277,256 & $219,547,144$ \\
\hline
\end{tabular}

209

210

211

212

213

214

The demand side however, shows a different story as the average occupancy has remained relatively stable, and ADR has slightly decreased since the inception of the platform on the Parisian market. Further, results of the time series analysis on monthly ADR are presented in Table 2 with the plots in Figure 1 and show that while Airbnb's ADR has slowly decreased over the examined period, hotels ADR has increased. Moreover, the average annual revenue per listing has been decreasing with the surge in the supply. In other words, as Airbnb gains popularity and its supply increases, the rentals are less profitable for hosts as the average number of bookings per listing has decreased over the past 4 years. This pattern differs from the hotel's one over the examined period in the Parisian market.

Table 2. Time series analysis: Monthly ADR (Airbnb and Hotels) 
Figure 1. Times series analysis: Monthly ADR (Airbnb vs. Hotels)
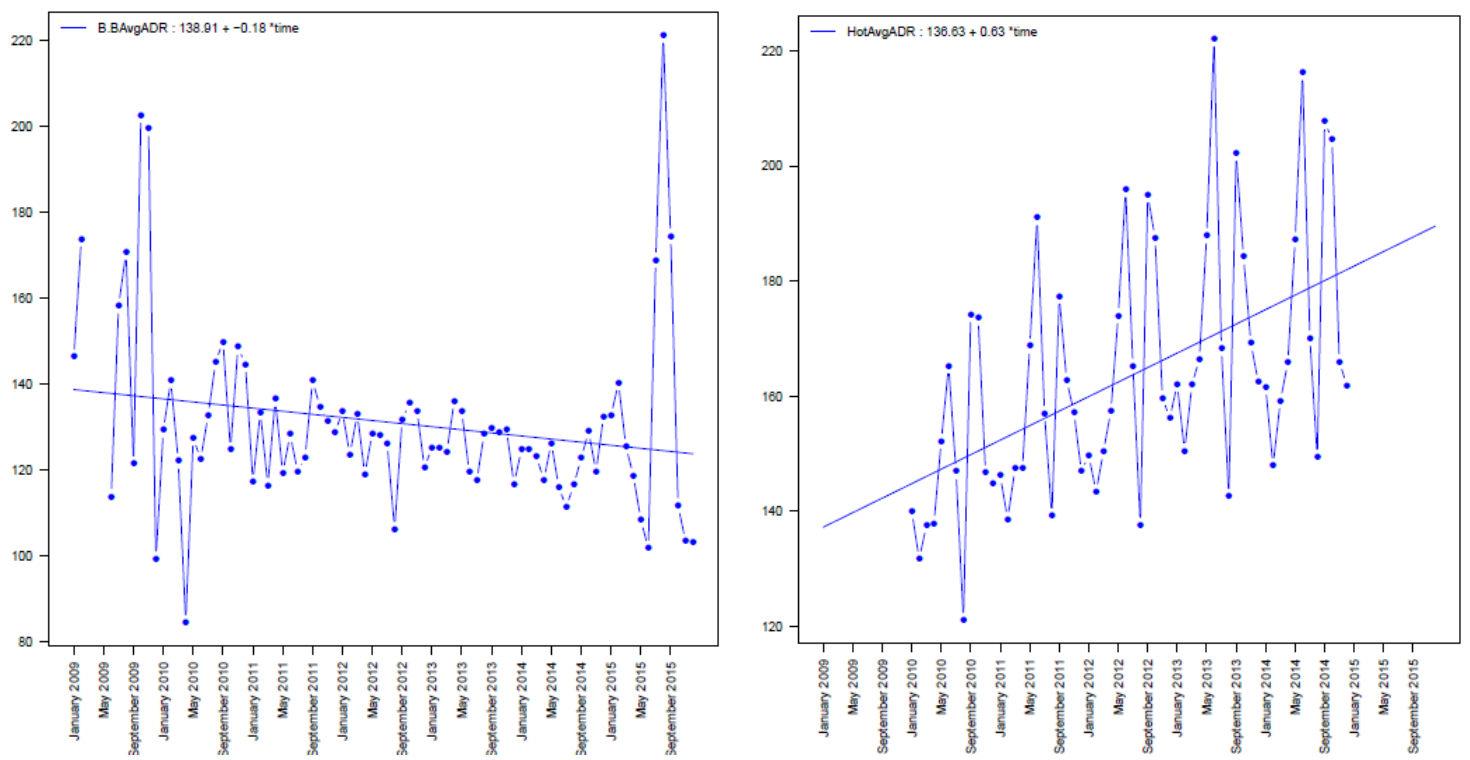

\subsection{Growing, but not as expected:}

The progression in the supply of Airbnb in total number of listings reflects the

exponential growth that has fuelled the debate so far in the industry. Nevertheless, when

comparing the annual growth rate to the number of rooms on the Parisian market, it is clear that hotel supply is growing steadily (Figure 2). Again, the Airbnb data reflect a plateau that the platform seems to reach after its first three to four years of operation.

Figure 2. Supply progression of hotel rooms vs. Airbnb listings (2010-2015) 


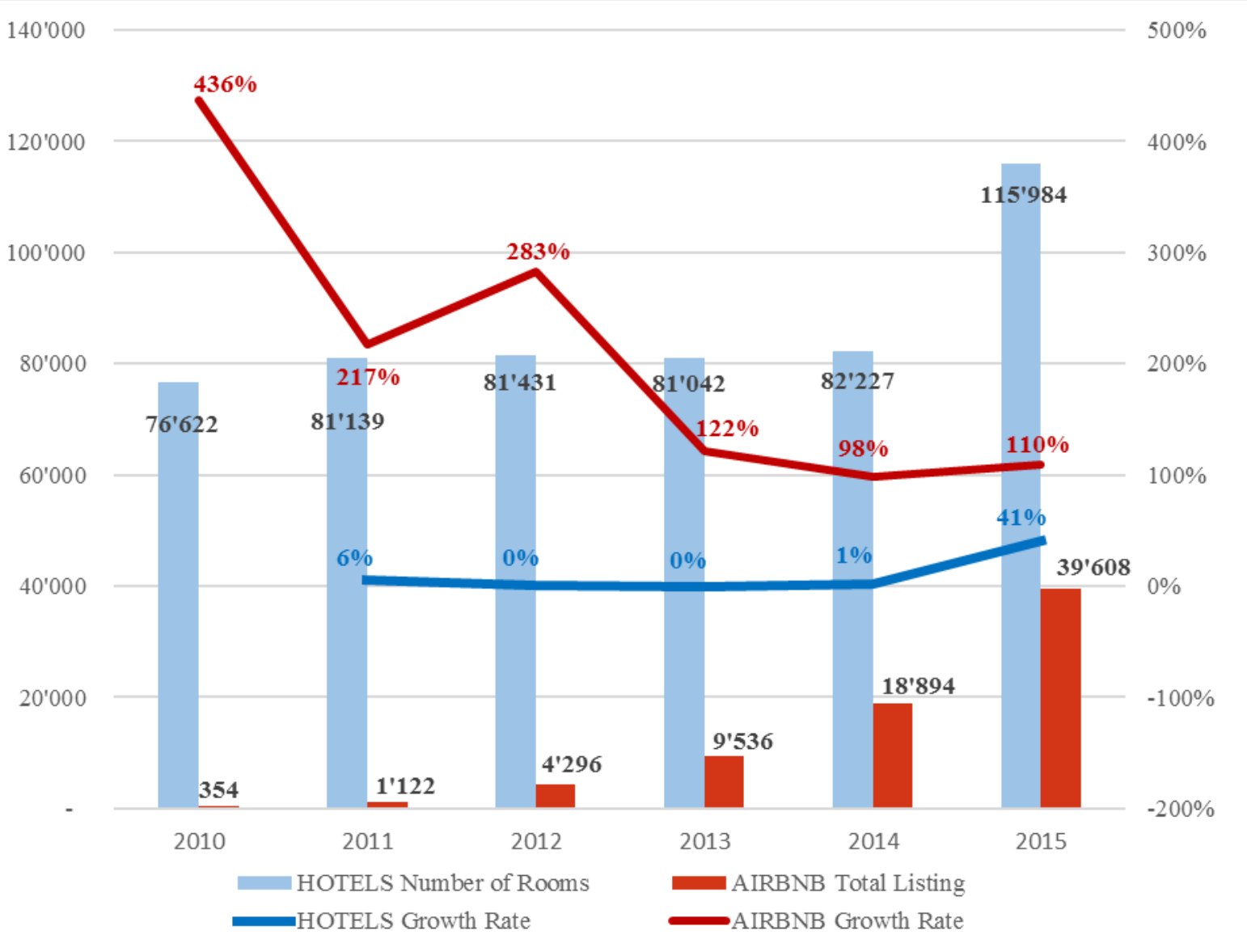

The Parisian hotel market developed between 2010 and 2015, with the opening of

241 hotels on the higher-end of the offer (Figure 3). Indeed, the number of rooms in the $4 *$

242 category has increased by more than $70 \%$ and $200 \%$ for the $5^{*}$ segment.

244 Figure 3. Hotel supply in number of rooms per category of hotel (2010-2015) 


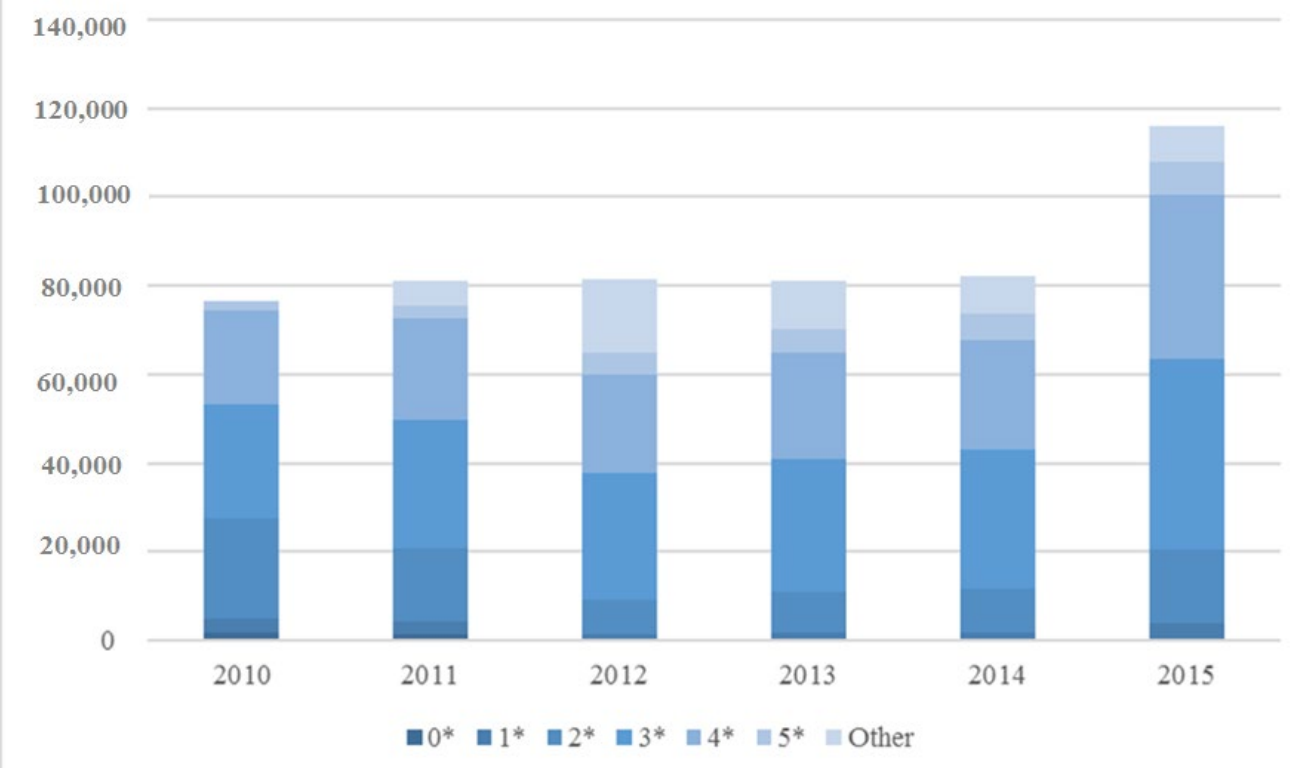

In terms of performance, our exploration of the Parisian market reveals that the Airbnb occupancy rate has been far below that of hotels. Figure 4 presents the average occupancy rate across hotels and Airbnb from 2009 to 2015. Blocked days were not included in the occupancy calculation for Airbnb. Hotels maintained a stable occupancy rate of approximately $80 \%$ over the period, whereas the Airbnb occupancy stayed around $55 \%$, peaking in 2010 at 55.9\%. In fact, Airbnb occupancy has registered a drop since 2012, reflecting the steady increase in the number of listings on the platform. Figure 5 illustrates the results of the times series analysis and reveals that while Airbnb's occupancy has slowly decreased over the period, hotels' has increased (See Table 3 and Figure 5).

Figure 4. Comparison of occupancy between hotels and Airbnb (2009-2015) 


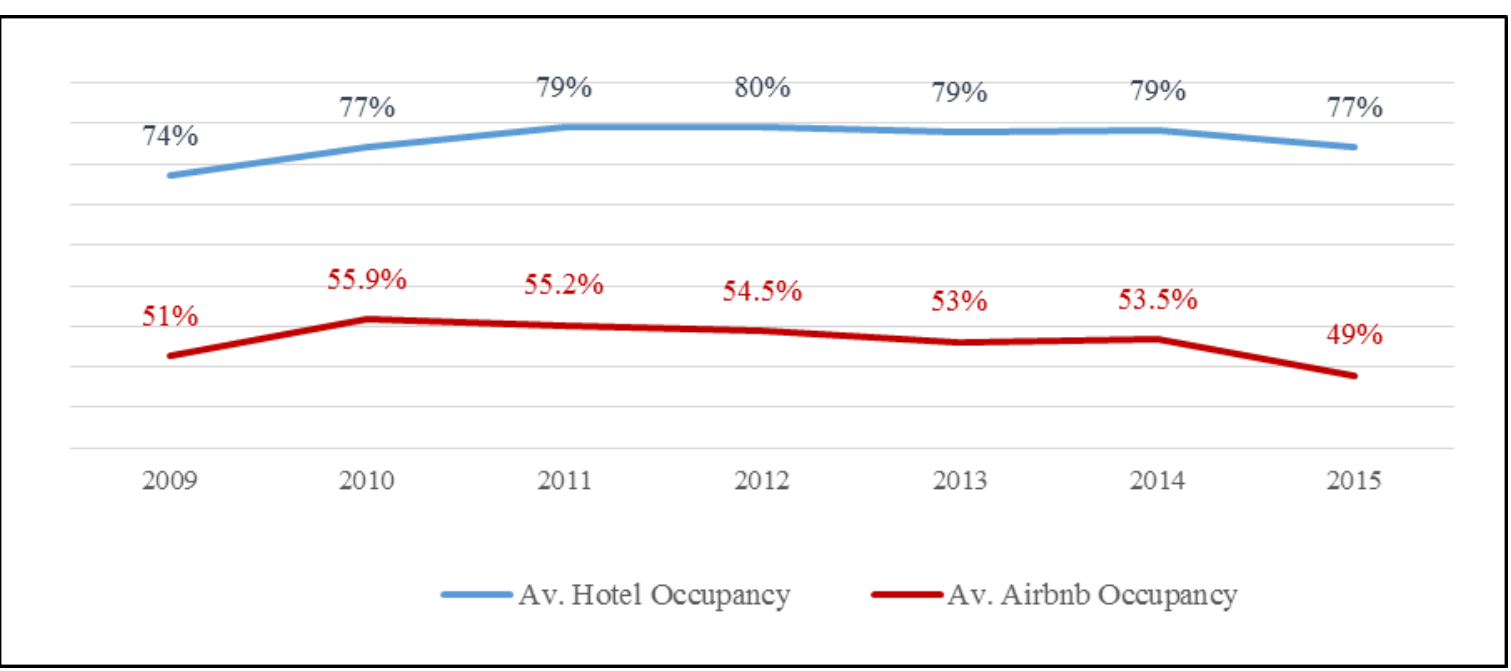

Table 3. Time series analysis: Monthly occupancy (Airbnb and Hotels)

\begin{tabular}{ccccc}
\hline Variable & Intercept & Trend & R2 & \\
\hline B\&B AvgOcc & $57.06(\mathrm{P}=0.00)$ & $-0.07(\mathrm{P}=0.00)$ & 0.12 & 261 \\
Hotel AvgOcc & $74.31(\mathrm{P}=0.00)$ & $0.1(\mathrm{P}=0.02)$ & 0.07 & \\
\hline
\end{tabular}

263

Figure 5. Time series analysis: Monthly occupancy (Airbnb and Hotels)

265
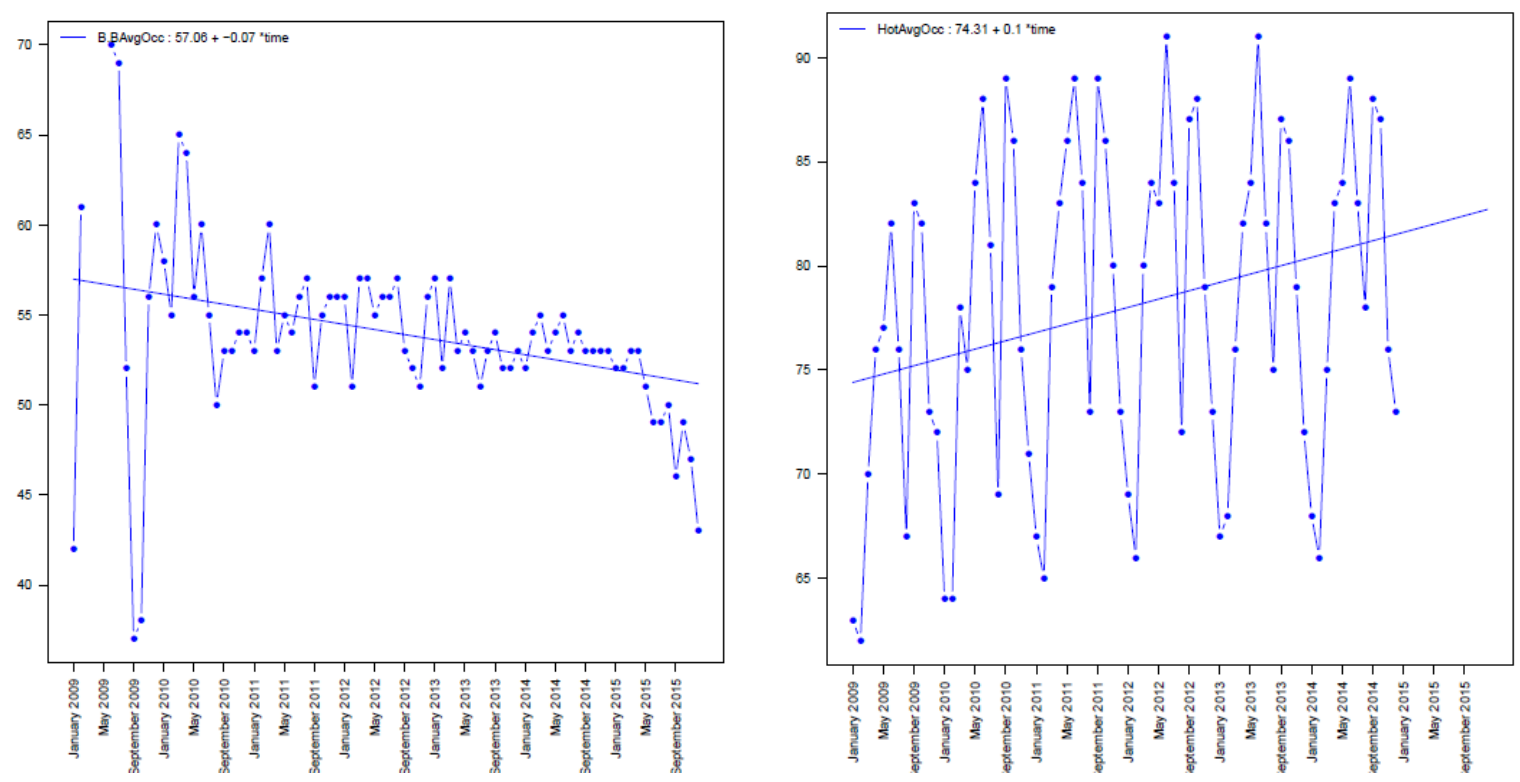

occupancy is stable despite an increase in the supply of 4- and 5-star hotels). As for Airbnb, it

273 boomed in its first 3 years, which is now reaching a plateau in terms of growth rate and 274 profitability for hosts.

Further, regression analyses were performance to identify the relationship between

Airbnb and hotel performance. According to the result of regression analysis in table 4,

Airbnb total revenue has a positive impact on hotel total revenue by month in Paris $(\mathrm{p}<0.01$, statistically affect hotel total revenue by month in Paris. Similarly, Airbnb total revenue has a positive impact on hotel average ADR by month in Paris $\left(\mathrm{p}<0.00\right.$, adjusted $\left.\mathrm{R}^{2}=0.3238\right)$. affect hotel average ADR by month in Paris (See table 5).

Table 4. Regression analysis - Hotel total revenue

\begin{tabular}{ccccc}
\hline \multicolumn{5}{c}{ HotelTotRev $=\beta_{0}+\beta_{1}$ B.BTotRev $+\beta_{2}$ B.BAvgADR $+\beta_{3}$ B.BnbBookings $+\varepsilon$} \\
\hline & Estimate & Std.Error & t-value & $\operatorname{Pr}(>|\mathrm{t}|)$ \\
\hline (Intercept) & $6.199 \mathrm{e}+06$ & $3.465 \mathrm{e}+06$ & 1.789 & 0.07898 \\
B.BTotRev & $7.342 \mathrm{e}-01$ & $2.489 \mathrm{e}-01$ & 2.950 & $0.00464 * * *$ \\
B.BAvgADR & $2.153 \mathrm{e}+04$ & $2.671 \mathrm{e}+04$ & 0.806 & 0.42357 \\
B.BnbBookings & $-1.947 \mathrm{e}+02$ & $1.259 \mathrm{e}+02$ & -1.546 & 0.12768 \\
\hline
\end{tabular}

Note: ${ }^{*} \mathrm{p}<0.10,{ }^{* *} \mathrm{p}<0.05,{ }^{* * *} \mathrm{p}<0.01$

287

Table 5. Regression analysis - Hotel monthly ADR

\begin{tabular}{ccccc}
\hline \multicolumn{5}{c}{ HotelADR $=\beta_{0}+\beta_{1}$ B.BTotRev $+\beta_{2}$ B. BAvgADR $+\beta_{3}$ B. BnbBookings $+\varepsilon$} \\
\hline & Estimate & Std.Error & t-value & $\operatorname{Pr}(>|\mathrm{t}|)$ \\
\hline (Intercept) & $1.163 \mathrm{e}+02$ & $3.018 \mathrm{e}+01$ & 3.854 & $0.000302 * * *$ \\
B.BTotRev & $6.635 \mathrm{e}-06$ & $2.168 \mathrm{e}-06$ & 3.060 & $0.003397 * * *$ \\
B.BAvgADR & $2.486 \mathrm{e}-01$ & $2.327 \mathrm{e}-01$ & 1.069 & 0.289807 \\
B.BnbBookings & $-1.502 \mathrm{e}-03$ & $1.097 \mathrm{e}-03$ & -1.369 & 0.176432 \\
\hline
\end{tabular}




\subsection{Different monthly patterns:}

Monthly data reflects a yearly uptick in Airbnb listings and uncovers a seasonality in

293

294

Figure 6. Airbnb average listings and average occupancy per month (2009-2015)

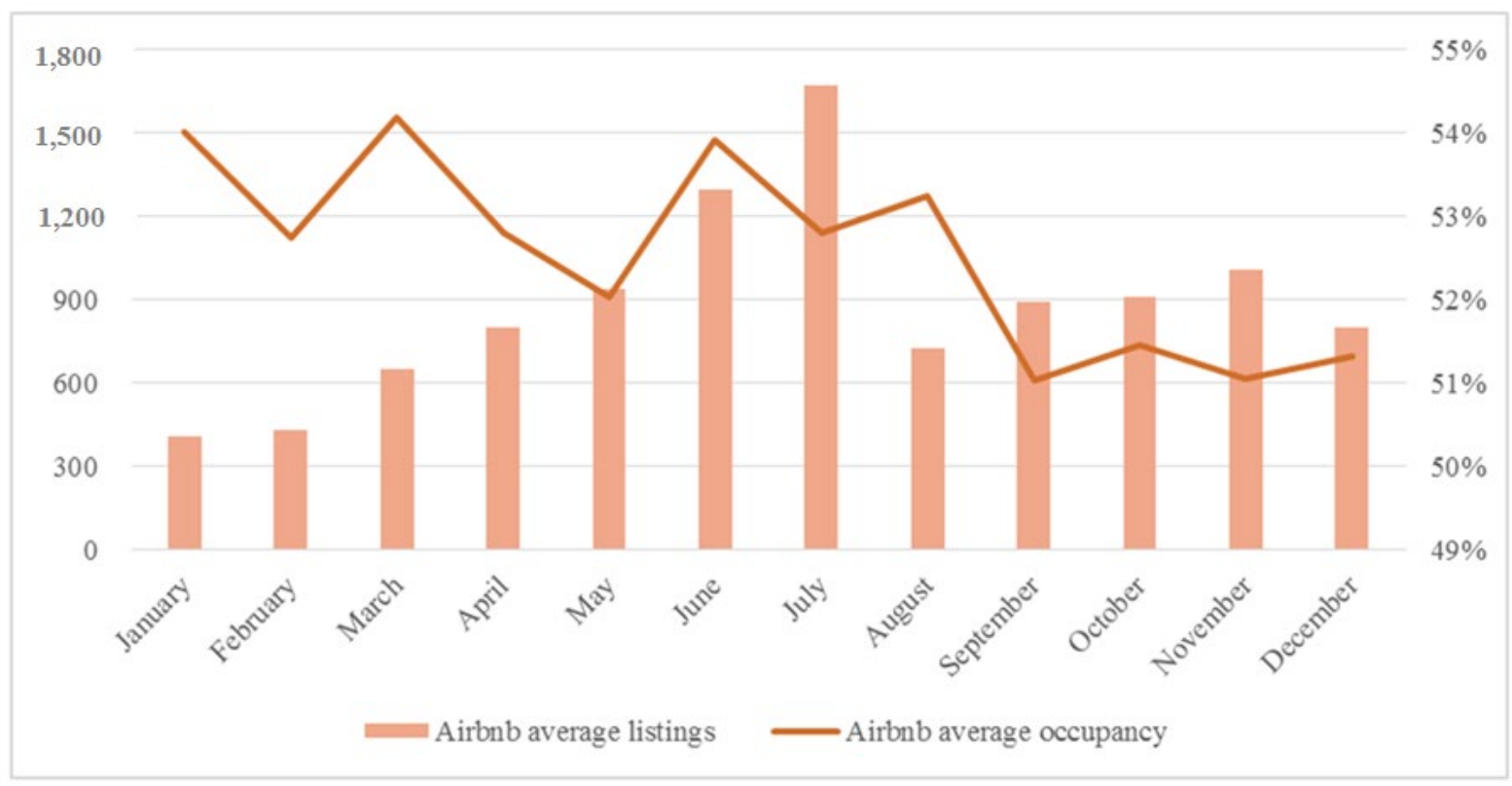

In general, the occupancy rate was higher in March and June each year than in other months (Figure 6). In 2010, there was a significant fluctuation in the occupancy rate across the peak season (i.e., March and April) and low season (i.e., August), which were the lowest occupancy months. In 2014, however, the occupancy rate remained stable over the year.

There are also patterns and seasonality in revenues, with higher revenues seen in the first two months of the year and then in August. Figure 7 shows the average annual Airbnb revenue in 
Paris between 2009 and 2015. Starting from 2013, the average annual revenue has started

308 decreasing across the months for the hosts registered on the platform.

309

Figure 7. Average annual revenue by Airbnb listing (2009-2015)

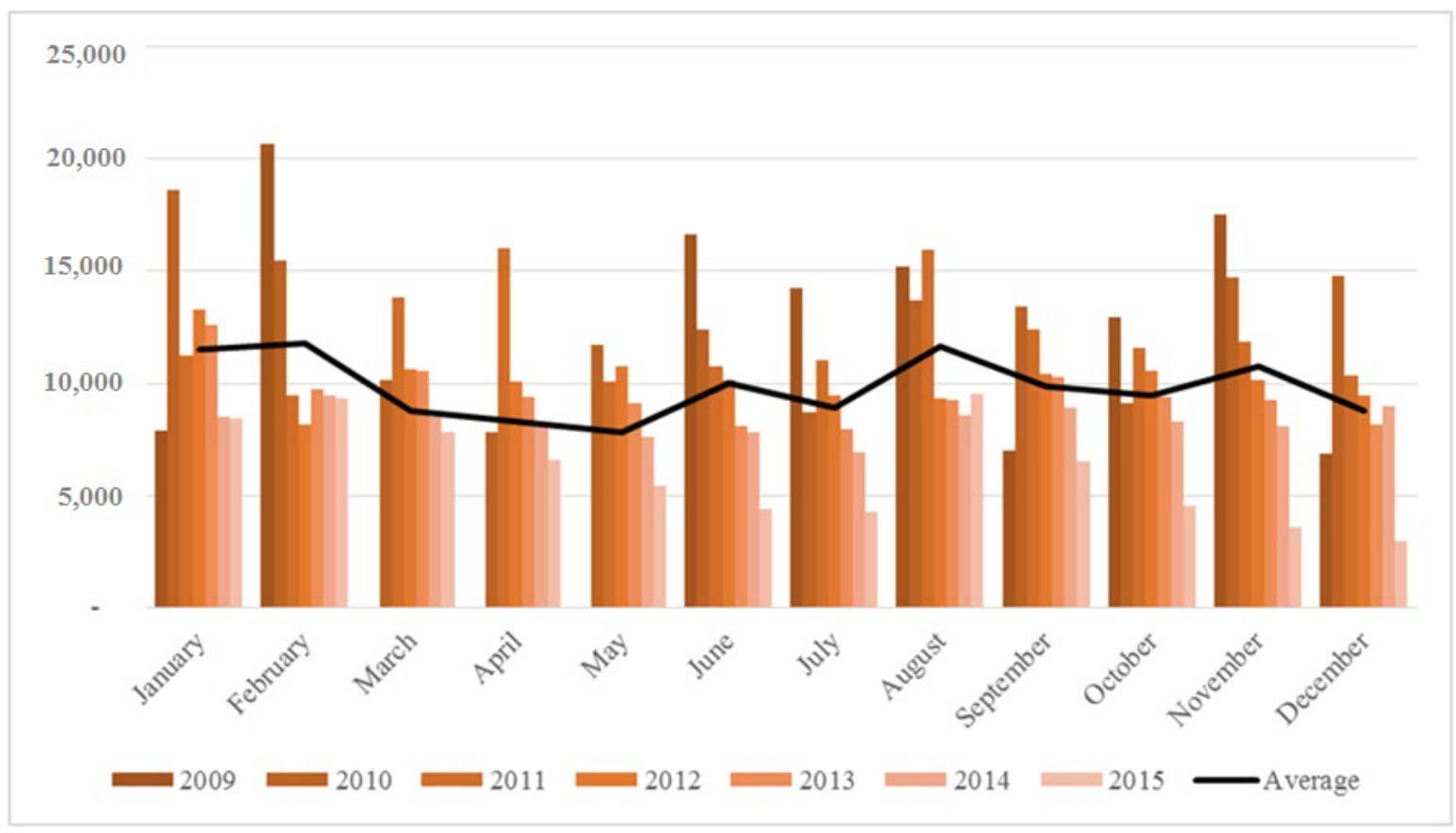

Overall, Airbnb shows a relatively stable occupancy rate of between $50 \%$ and $55 \%$ over the year. Figure 8 compares the occupancy rate in 2014 between hotels and Airbnb. Hotel occupancy, however, fluctuated between 65 and 90\% over the year. June and September recorded the highest occupancy rates of $90 \%$ and $88 \%$. The occupancy rate remained significantly low throughout the winter season (i.e., December to February). As shown in Figure 9, average ADR by month showed greater variance compared to that of Airbnb.

Figure 8. Occupancy rates by month Hotels vs. Airbnb (2014) 

among different districts. Table 6 and Table 7 show the distribution of hotel rooms and

331

Figure 9. Average ADR: Hotels vs. Airbnb (2009-2015)

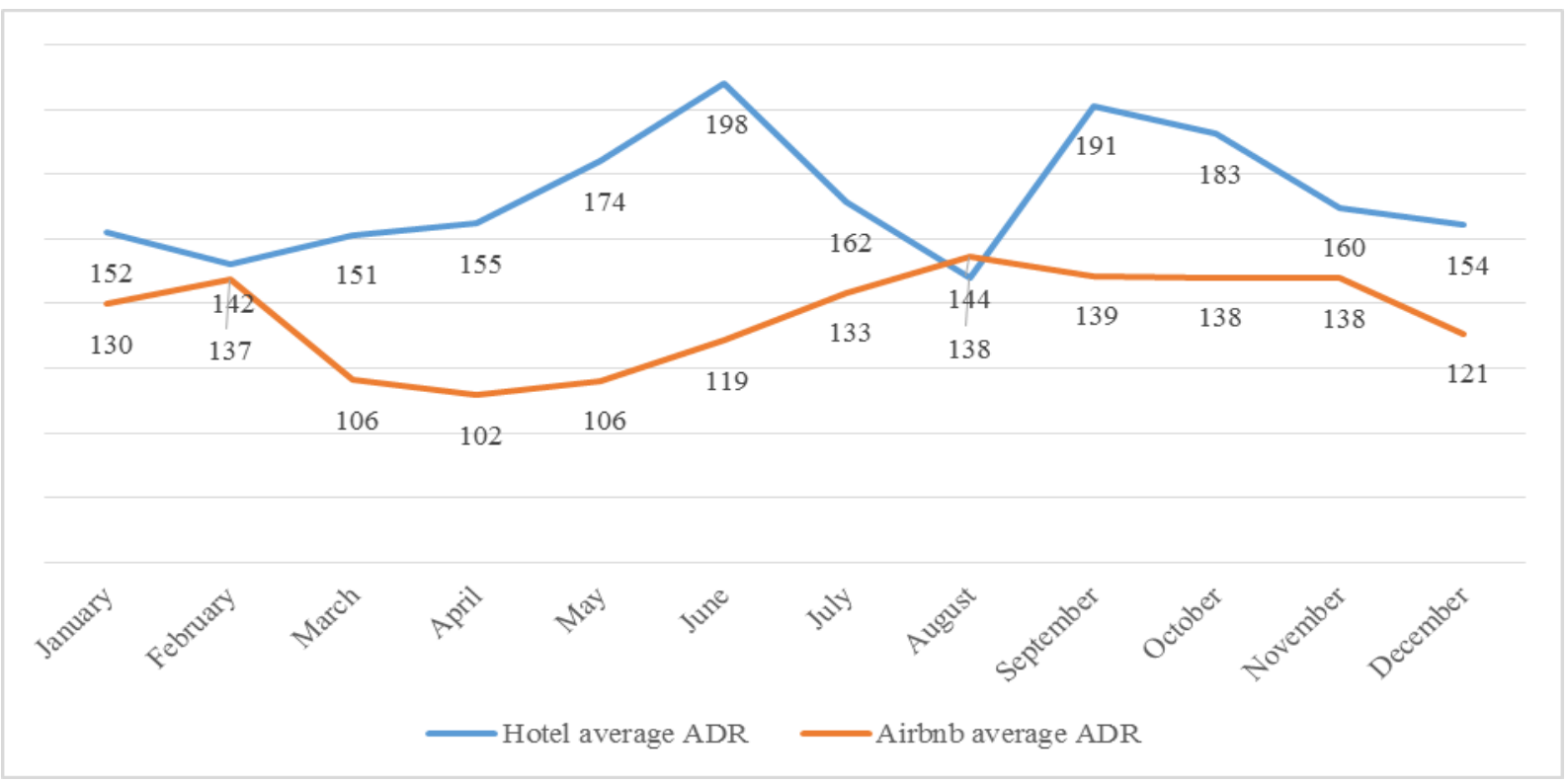

\subsection{Different geographic patterns.}

As Airbnb and hotels appear to show different (and maybe complementary) patterns in supply and demand, we investigated the performance of both products by location. As Paris is divided into twenty administrative districts, we examined whether there are any differences Airbnb listings per administrative districts respectively and Figure 10 shows the top five

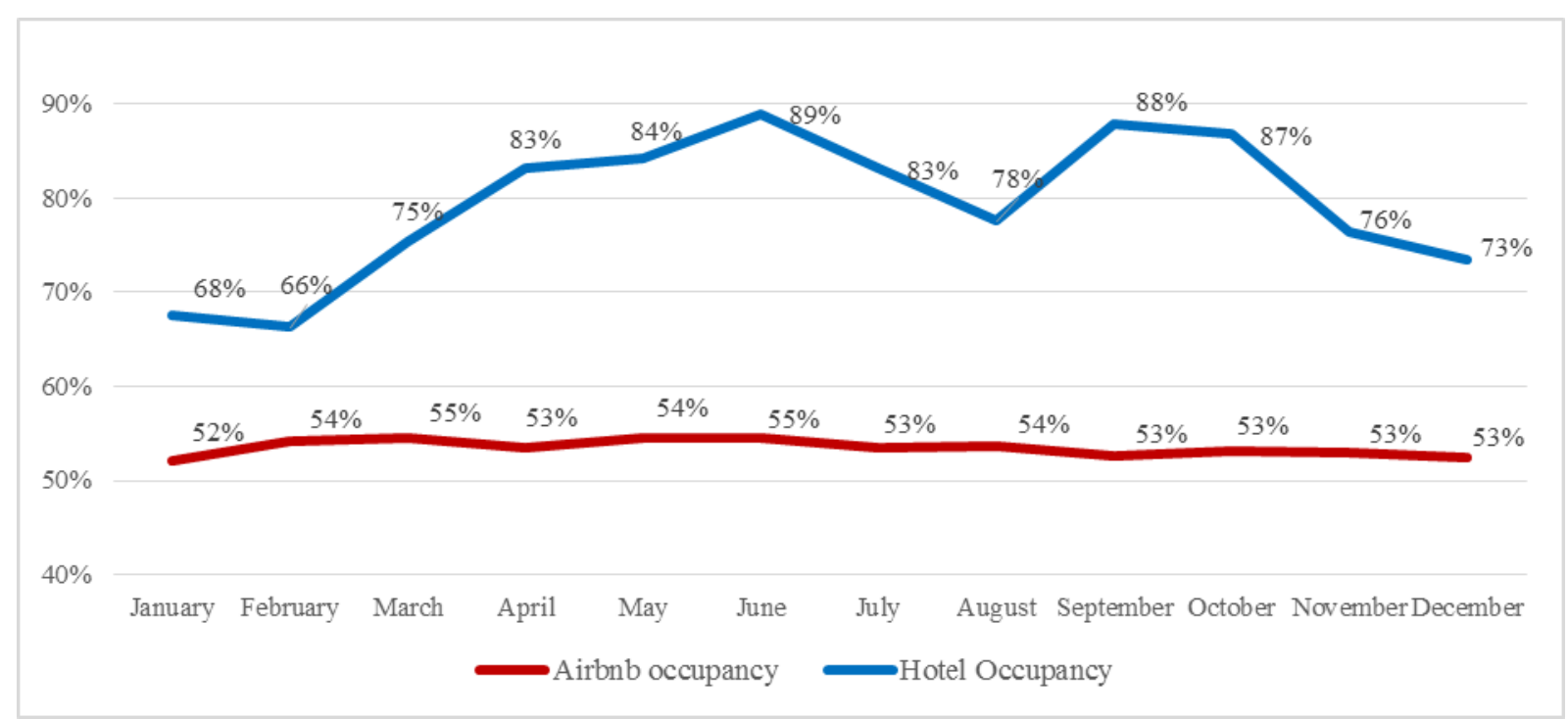


332 districts in terms of supply of hotel rooms and Airbnb listings in 2014. The locations of hotels

333 and Airbnb properties look quite different. While most hotel rooms are located in districts 9, 8

334 and 17, district 18 and 11 ranked the top districts for Airbnb listings. Both the $18^{\text {th }}$ district and

$33511^{\text {th }}$ district are located on the Rive Droite and the $11^{\text {th }}$ district is the most populated area in

336 Paris.

337 Table 6. The distribution of hotel rooms by administrative district in Pars (2010-2014)

\begin{tabular}{cccccc}
\hline Districts & $\mathbf{2 0 1 0}$ & $\mathbf{2 0 1 1}$ & $\mathbf{2 0 1 2}$ & $\mathbf{2 0 1 3}$ & $\mathbf{2 0 1 4}$ \\
\hline $\mathbf{9}$ & $11.8 \%$ & $10.7 \%$ & $10.6 \%$ & $10.6 \%$ & $10.5 \%$ \\
\hline $\mathbf{8}$ & $11.5 \%$ & $10.7 \%$ & $10.5 \%$ & $10.6 \%$ & $10.6 \%$ \\
\hline $\mathbf{1 7}$ & $9.4 \%$ & $9.3 \%$ & $9.1 \%$ & $9.2 \%$ & $9.2 \%$ \\
\hline $\mathbf{1 5}$ & $8.9 \%$ & $9.1 \%$ & $9.0 \%$ & $8.2 \%$ & $8.2 \%$ \\
\hline $\mathbf{1 4}$ & $8.0 \%$ & $8.1 \%$ & $8.1 \%$ & $8.2 \%$ & $8.1 \%$ \\
\hline $\mathbf{1 0}$ & $7.3 \%$ & $6.7 \%$ & $6.8 \%$ & $6.9 \%$ & $7.0 \%$ \\
\hline $\mathbf{1 2}$ & $5.8 \%$ & $5.6 \%$ & $6.0 \%$ & $5.6 \%$ & $5.5 \%$ \\
\hline $\mathbf{1}$ & $5.3 \%$ & $5.2 \%$ & $5.2 \%$ & $5.2 \%$ & $5.1 \%$ \\
\hline $\mathbf{6}$ & $5.0 \%$ & $4.8 \%$ & $4.7 \%$ & $4.6 \%$ & $4.6 \%$ \\
\hline $\mathbf{5}$ & $3.8 \%$ & $3.7 \%$ & $3.7 \%$ & $3.7 \%$ & $3.7 \%$ \\
\hline $\mathbf{1 1}$ & $3.7 \%$ & $3.7 \%$ & $3.8 \%$ & $4.1 \%$ & $4.1 \%$ \\
\hline $\mathbf{1 8}$ & $3.5 \%$ & $5.3 \%$ & $5.5 \%$ & $5.6 \%$ & $5.6 \%$ \\
\hline $\mathbf{1 6}$ & $3.3 \%$ & $3.5 \%$ & $3.4 \%$ & $3.5 \%$ & $3.8 \%$ \\
\hline $\mathbf{7}$ & $2.90 \%$ & $2.7 \%$ & $2.7 \%$ & $2.6 \%$ & $2.7 \%$ \\
\hline $\mathbf{1 3}$ & $2.8 \%$ & $2.5 \%$ & $2.6 \%$ & $2.6 \%$ & $2.6 \%$ \\
\hline $\mathbf{1 9}$ & $2.2 \%$ & $2.7 \%$ & $2.7 \%$ & $2.7 \%$ & $2.8 \%$ \\
\hline $\mathbf{2}$ & $2.0 \%$ & $2.0 \%$ & $2.0 \%$ & $2.0 \%$ & $2.1 \%$ \\
\hline $\mathbf{3}$ & $1.1 \%$ & $1.2 \%$ & $1.2 \%$ & $1.2 \%$ & $1.2 \%$ \\
\hline $\mathbf{4}$ & $1.1 \%$ & $1.1 \%$ & $1.1 \%$ & $1.1 \%$ & $1.1 \%$ \\
\hline $\mathbf{2 0}$ & $0.7 \%$ & $1.4 \%$ & $1.4 \%$ & $1.7 \%$ & $1.6 \%$ \\
\hline
\end{tabular}

Table 7. The distribution of Airbnb listings by administrative districts in Paris (2009-2015)

\begin{tabular}{cccccccc}
\hline Districts & $\mathbf{2 0 0 9}$ & $\mathbf{2 0 1 0}$ & $\mathbf{2 0 1 1}$ & $\mathbf{2 0 1 2}$ & $\mathbf{2 0 1 3}$ & $\mathbf{2 0 1 4}$ & $\mathbf{2 0 1 5}$ \\
\hline $\mathbf{1 8}$ & $15.2 \%$ & $12.9 \%$ & $13.1 \%$ & $13.2 \%$ & $12.7 \%$ & $12.5 \%$ & $11.4 \%$ \\
\hline $\mathbf{1 1}$ & $18.2 \%$ & $11.6 \%$ & $9.9 \%$ & $11.0 \%$ & $10.0 \%$ & $9.2 \%$ & $9.0 \%$ \\
\hline $\mathbf{1 5}$ & $6.1 \%$ & $2.5 \%$ & $4.4 \%$ & $4.9 \%$ & $6.1 \%$ & $7.1 \%$ & $8.3 \%$ \\
\hline $\mathbf{1 7}$ & $1.5 \%$ & $3.2 \%$ & $4.6 \%$ & $4.6 \%$ & $5.5 \%$ & $6.7 \%$ & $6.9 \%$ \\
\hline $\mathbf{1 0}$ & $7.6 \%$ & $6.4 \%$ & $7.0 \%$ & $8.3 \%$ & $7.6 \%$ & $6.9 \%$ & $6.5 \%$ \\
\hline $\mathbf{1 6}$ & $0.0 \%$ & $2.0 \%$ & $2.5 \%$ & $3.6 \%$ & $3.8 \%$ & $4.6 \%$ & $5.7 \%$ \\
\hline $\mathbf{2 0}$ & $3.0 \%$ & $1.8 \%$ & $5.3 \%$ & $5.8 \%$ & $5.5 \%$ & $5.8 \%$ & $5.4 \%$ \\
\hline $\mathbf{1 9}$ & $7.6 \%$ & $1.8 \%$ & $5.2 \%$ & $5.2 \%$ & $5.6 \%$ & $5.7 \%$ & $5.1 \%$ \\
\hline $\mathbf{9}$ & $7.6 \%$ & $1.5 \%$ & $4.7 \%$ & $4.9 \%$ & $4.9 \%$ & $4.7 \%$ & $4.4 \%$ \\
\hline $\mathbf{3}$ & $12.1 \%$ & $8.8 \%$ & $7.5 \%$ & $6.1 \%$ & $5.4 \%$ & $4.6 \%$ & $4.2 \%$ \\
\hline $\mathbf{1 2}$ & $0.0 \%$ & $3.2 \%$ & $2.1 \%$ & $2.6 \%$ & $3.0 \%$ & $3.7 \%$ & $3.8 \%$ \\
\hline
\end{tabular}




\begin{tabular}{cccccccc}
\hline $\mathbf{1 3}$ & $6.1 \%$ & $3.8 \%$ & $2.6 \%$ & $2.9 \%$ & $3.1 \%$ & $3.3 \%$ & $3.8 \%$ \\
\hline $\mathbf{1 4}$ & $0.0 \%$ & $0.3 \%$ & $3.5 \%$ & $2.8 \%$ & $3.1 \%$ & $3.1 \%$ & $3.6 \%$ \\
\hline $\mathbf{4}$ & $9.1 \%$ & $10.2 \%$ & $5.0 \%$ & $5.5 \%$ & $4.9 \%$ & $3.6 \%$ & $3.5 \%$ \\
\hline $\mathbf{5}$ & $1.5 \%$ & $6.2 \%$ & $4.2 \%$ & $4.1 \%$ & $3.9 \%$ & $3.7 \%$ & $3.5 \%$ \\
\hline $\mathbf{6}$ & $0.0 \%$ & $5.1 \%$ & $3.7 \%$ & $3.5 \%$ & $3.6 \%$ & $3.3 \%$ & $3.4 \%$ \\
\hline $\mathbf{7}$ & $0.0 \%$ & $5.2 \%$ & $3.1 \%$ & $2.4 \%$ & $3.0 \%$ & $3.2 \%$ & $3.4 \%$ \\
\hline $\mathbf{2}$ & $1.5 \%$ & $4.2 \%$ & $4.5 \%$ & $4.1 \%$ & $3.5 \%$ & $3.3 \%$ & $3.0 \%$ \\
\hline $\mathbf{8}$ & $1.5 \%$ & $2.8 \%$ & $2.9 \%$ & $2.0 \%$ & $2.3 \%$ & $2.4 \%$ & $2.8 \%$ \\
\hline $\mathbf{1}$ & $1.5 \%$ & $6.6 \%$ & $4.2 \%$ & $2.5 \%$ & $2.3 \%$ & $2.5 \%$ & $2.0 \%$ \\
\hline
\end{tabular}

341 Figure 10. Distribution of hotel room supply and Airbnb listing by district: Top 5 districts 342 (2014)

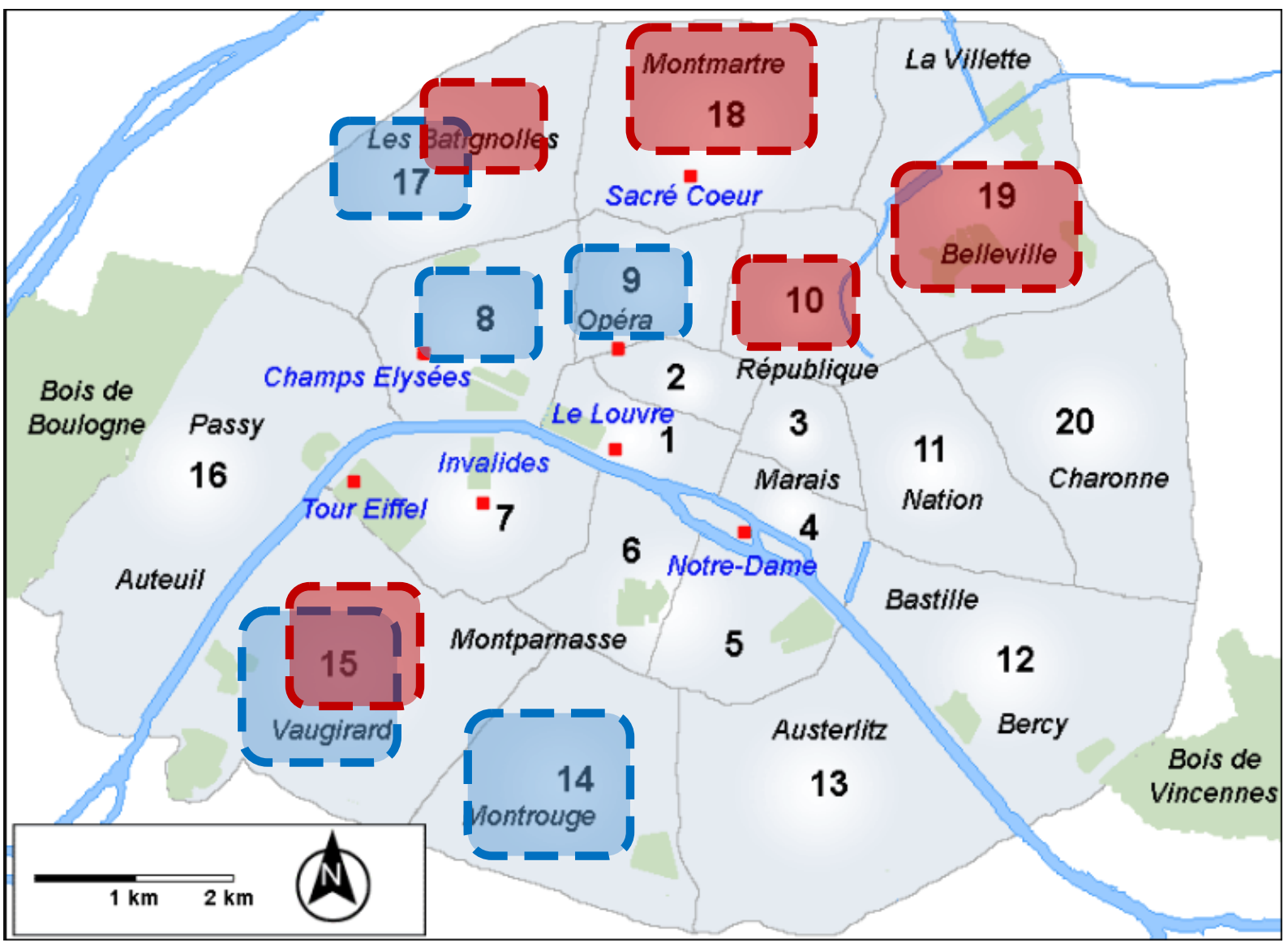

Note: The size of box does not reflect the size of supply.

Further, Table 8, Table 9, Table 10 and Table 11 exhibit the total number of bookings,

average occupancy, ADR, and the total revenue of Airbnb by administrative district in Paris.

And they show great discrepancies among administrative districts. Again, the $18^{\text {th }}$ and $11^{\text {th }}$ districts rank top districts in terms of the total number of bookings. On the other hand, only 

highest (\$351.07) and its total revenue ranked third.

353 Table 8. Total number of Airbnb bookings by administrative district in Paris (2009-2015)

\begin{tabular}{cccccccc}
\hline Districts & $\mathbf{2 0 0 9}$ & $\mathbf{2 0 1 0}$ & $\mathbf{2 0 1 1}$ & $\mathbf{2 0 1 2}$ & $\mathbf{2 0 1 3}$ & $\mathbf{2 0 1 4}$ & $\mathbf{2 0 1 5}$ \\
\hline $\mathbf{1 8}$ & 90 & 721 & 1,958 & 5,711 & 11,740 & 21,826 & 29,577 \\
\hline $\mathbf{1 1}$ & 238 & 648 & 1,247 & 5,985 & 8,975 & 14,888 & 24,361 \\
\hline $\mathbf{1 5}$ & 53 & 137 & 742 & 2,883 & 5,906 & 12,005 & 24,244 \\
\hline $\mathbf{1 0}$ & 96 & 357 & 1,036 & 4,065 & 7,840 & 12,045 & 19,794 \\
\hline $\mathbf{1 7}$ & 7 & 176 & 742 & 1,931 & 4,559 & 10,599 & 17,591 \\
\hline $\mathbf{3}$ & 65 & 494 & 1,799 & 4,543 & 8,636 & 13,656 & 17,067 \\
\hline $\mathbf{4}$ & 220 & 569 & 1,341 & 5,664 & 9,088 & 10,635 & 15,068 \\
\hline $\mathbf{1 6}$ & 0 & 113 & 452 & 1,983 & 4,232 & 9,210 & 14,659 \\
\hline $\mathbf{2}$ & 5 & 234 & 1,066 & 2,895 & 5,427 & 9,940 & 13,663 \\
\hline $\mathbf{9}$ & 52 & 83 & 628 & 1,953 & 5,446 & 9,284 & 12,513 \\
\hline $\mathbf{5}$ & 53 & 347 & 1,070 & 3,688 & 5,312 & 8,390 & 12,234 \\
\hline $\mathbf{6}$ & 0 & 285 & 629 & 3,287 & 5,856 & 9,165 & 11,855 \\
\hline $\mathbf{1 9}$ & 14 & 102 & 376 & 1,636 & 3,131 & 6,904 & 11,815 \\
\hline $\mathbf{2 0}$ & 1 & 101 & 463 & 2,514 & 3,027 & 7,254 & 11,760 \\
\hline $\mathbf{1 2}$ & 0 & 180 & 264 & 1,324 & 2,710 & 7,007 & 11,580 \\
\hline $\mathbf{7}$ & 0 & 288 & 602 & 1,784 & 4,361 & 8,182 & 10,769 \\
\hline $\mathbf{1 4}$ & 0 & 14 & 470 & 950 & 2,723 & 5,070 & 10,138 \\
\hline $\mathbf{1 3}$ & 75 & 212 & 393 & 1,146 & 2,033 & 5,027 & 9,275 \\
\hline $\mathbf{8}$ & 11 & 155 & 465 & 1,126 & 3,440 & 6,037 & 9,039 \\
\hline $\mathbf{1}$ & 0 & 370 & 995 & 2,536 & 4,110 & 8,230 & 8,501 \\
\hline
\end{tabular}

356 Table 9. Average Airbnb occupancy rates by administrative district in Paris (2009-2015)

\begin{tabular}{cccccccc}
\hline Districts & $\mathbf{2 0 0 9}$ & $\mathbf{2 0 1 0}$ & $\mathbf{2 0 1 1}$ & $\mathbf{2 0 1 2}$ & $\mathbf{2 0 1 3}$ & $\mathbf{2 0 1 4}$ & $\mathbf{2 0 1 5}$ \\
\hline $\mathbf{1 1}$ & $60.5 \%$ & $62.5 \%$ & $54.9 \%$ & $57.6 \%$ & $53.6 \%$ & $55.4 \%$ & $53.0 \%$ \\
\hline $\mathbf{1 2}$ & $0.0 \%$ & $58.4 \%$ & $54.6 \%$ & $58.0 \%$ & $53.0 \%$ & $55.4 \%$ & $51.6 \%$ \\
\hline $\mathbf{1 0}$ & $53.8 \%$ & $63.6 \%$ & $61.3 \%$ & $55.4 \%$ & $54.3 \%$ & $54.8 \%$ & $51.6 \%$ \\
\hline $\mathbf{1 3}$ & $52.7 \%$ & $60.8 \%$ & $57.5 \%$ & $57.0 \%$ & $48.1 \%$ & $52.8 \%$ & $50.9 \%$ \\
\hline $\mathbf{5}$ & $77.8 \%$ & $65.4 \%$ & $61.1 \%$ & $60.4 \%$ & $56.6 \%$ & $56.3 \%$ & $50.7 \%$ \\
\hline $\mathbf{2 0}$ & $29.4 \%$ & $53.8 \%$ & $54.2 \%$ & $55.4 \%$ & $51.7 \%$ & $52.4 \%$ & $50.7 \%$ \\
\hline $\mathbf{2}$ & $40.5 \%$ & $56.9 \%$ & $61.1 \%$ & $53.5 \%$ & $56.0 \%$ & $54.5 \%$ & $50.5 \%$ \\
\hline $\mathbf{1 4}$ & $0.0 \%$ & $31.5 \%$ & $52.6 \%$ & $48.6 \%$ & $49.0 \%$ & $53.2 \%$ & $50.0 \%$ \\
\hline $\mathbf{1}$ & $0.0 \%$ & $68.2 \%$ & $59.0 \%$ & $55.2 \%$ & $56.6 \%$ & $57.9 \%$ & $50.0 \%$ \\
\hline $\mathbf{4}$ & $66.6 \%$ & $61.9 \%$ & $57.0 \%$ & $60.7 \%$ & $54.5 \%$ & $57.0 \%$ & $49.5 \%$ \\
\hline $\mathbf{3}$ & $50.3 \%$ & $61.7 \%$ & $56.8 \%$ & $53.6 \%$ & $53.6 \%$ & $55.1 \%$ & $49.4 \%$ \\
\hline
\end{tabular}




\begin{tabular}{cccccccc}
\hline $\mathbf{1 5}$ & $47.9 \%$ & $52.6 \%$ & $53.2 \%$ & $55.6 \%$ & $53.8 \%$ & $52.8 \%$ & $49.0 \%$ \\
\hline $\mathbf{1 8}$ & $26.0 \%$ & $51.6 \%$ & $52.9 \%$ & $52.5 \%$ & $51.9 \%$ & $51.8 \%$ & $48.3 \%$ \\
\hline $\mathbf{1 9}$ & $45.1 \%$ & $38.8 \%$ & $46.0 \%$ & $47.7 \%$ & $51.2 \%$ & $49.5 \%$ & $48.2 \%$ \\
\hline $\mathbf{9}$ & $59.9 \%$ & $36.7 \%$ & $48.9 \%$ & $51.4 \%$ & $51.9 \%$ & $52.2 \%$ & $48.2 \%$ \\
\hline $\mathbf{1 7}$ & $30.9 \%$ & $50.8 \%$ & $53.8 \%$ & $50.5 \%$ & $51.7 \%$ & $50.5 \%$ & $47.3 \%$ \\
\hline $\mathbf{6}$ & $0.0 \%$ & $63.9 \%$ & $55.2 \%$ & $54.3 \%$ & $57.4 \%$ & $53.4 \%$ & $47.1 \%$ \\
\hline $\mathbf{7}$ & $0.0 \%$ & $61.7 \%$ & $56.1 \%$ & $58.6 \%$ & $54.2 \%$ & $54.9 \%$ & $46.3 \%$ \\
\hline $\mathbf{8}$ & $78.1 \%$ & $41.3 \%$ & $48.6 \%$ & $47.1 \%$ & $51.6 \%$ & $52.9 \%$ & $44.1 \%$ \\
\hline $\mathbf{1 6}$ & $0.0 \%$ & $43.5 \%$ & $54.6 \%$ & $50.2 \%$ & $50.2 \%$ & $51.5 \%$ & $42.8 \%$ \\
\hline
\end{tabular}

359 Table 10. ADR of Airbnb listings by administrative district in Paris (2009-2015)

\begin{tabular}{cccccccc}
\hline Districts & $\mathbf{2 0 0 9}$ & $\mathbf{2 0 1 0}$ & $\mathbf{2 0 1 1}$ & $\mathbf{2 0 1 2}$ & $\mathbf{2 0 1 3}$ & $\mathbf{2 0 1 4}$ & $\mathbf{2 0 1 5}$ \\
\hline $\mathbf{3}$ & 157.97 & 112.67 & 149.22 & 143.37 & 154.60 & 147.01 & 351.07 \\
\hline $\mathbf{8}$ & 109.29 & 216.06 & 236.85 & 184.59 & 179.01 & 228.52 & 258.06 \\
\hline $\mathbf{4}$ & 248.10 & 202.43 & 154.80 & 152.36 & 167.52 & 155.41 & 162.27 \\
\hline $\mathbf{6}$ & 0.00 & 177.99 & 190.80 & 163.12 & 180.42 & 175.06 & 160.74 \\
\hline $\mathbf{1}$ & 0.00 & 161.65 & 152.04 & 169.32 & 160.46 & 174.74 & 155.64 \\
\hline $\mathbf{7}$ & 0.00 & 159.36 & 161.44 & 159.53 & 168.86 & 178.44 & 151.53 \\
\hline $\mathbf{1 6}$ & 0.00 & 139.26 & 186.02 & 145.76 & 158.63 & 142.02 & 141.80 \\
\hline $\mathbf{1 1}$ & 108.75 & 123.71 & 108.26 & 109.33 & 107.12 & 100.13 & 141.04 \\
\hline $\mathbf{1 8}$ & 132.89 & 102.79 & 105.90 & 105.96 & 96.46 & 99.80 & 139.33 \\
\hline $\mathbf{2}$ & 127.84 & 116.18 & 131.09 & 158.38 & 145.98 & 147.75 & 133.46 \\
\hline $\mathbf{5}$ & 81.39 & 131.90 & 141.29 & 140.18 & 151.73 & 133.23 & 123.98 \\
\hline $\mathbf{9}$ & 102.27 & 103.88 & 111.62 & 135.33 & 125.98 & 121.31 & 111.70 \\
\hline $\mathbf{1 0}$ & 106.48 & 90.75 & 106.61 & 113.94 & 109.88 & 103.90 & 101.44 \\
\hline $\mathbf{1 7}$ & 200.48 & 138.68 & 152.32 & 125.83 & 104.09 & 111.98 & 99.85 \\
\hline $\mathbf{1 5}$ & 240.95 & 151.52 & 119.10 & 129.14 & 118.72 & 110.48 & 99.60 \\
\hline $\mathbf{1 4}$ & 0.00 & 170.18 & 101.74 & 122.05 & 112.97 & 98.50 & 95.28 \\
\hline $\mathbf{1 2}$ & 0.00 & 116.17 & 102.73 & 111.12 & 102.84 & 98.51 & 84.22 \\
\hline $\mathbf{1 3}$ & 112.66 & 93.69 & 91.47 & 102.67 & 96.01 & 88.36 & 79.24 \\
\hline $\mathbf{1 9}$ & 98.69 & 113.14 & 87.87 & 89.45 & 86.49 & 84.35 & 72.30 \\
\hline $\mathbf{2 0}$ & 49.00 & 87.53 & 75.77 & 82.38 & 79.81 & 79.15 & 69.43 \\
\hline & & & & & & & \\
\hline & & & & & & \\
\hline
\end{tabular}

362 Table 11. Total Airbnb revenue by administrative district in Paris (2009-2015)

\begin{tabular}{cccccccc}
\hline Districts & $\mathbf{2 0 0 9}$ & $\mathbf{2 0 1 0}$ & $\mathbf{2 0 1 1}$ & $\mathbf{2 0 1 2}$ & $\mathbf{2 0 1 3}$ & $\mathbf{2 0 1 4}$ & $\mathbf{2 0 1 5}$ \\
\hline $\mathbf{1 8}$ & 34,511 & 320,824 & 925,446 & $2,548,882$ & $4,860,132$ & $8,599,536$ & $14,605,641$ \\
\hline $\mathbf{1 1}$ & 106,828 & 385,063 & 744,751 & $3,090,023$ & $4,555,431$ & $7,290,694$ & $14,270,196$ \\
\hline $\mathbf{3}$ & 60,409 & 205,388 & $1,158,811$ & $2,770,841$ & $5,630,981$ & $8,366,997$ & $10,970,884$ \\
\hline $\mathbf{8}$ & 23,061 & 82,924 & 468,068 & 903,665 & $2,389,453$ & $4,855,422$ & $10,859,226$ \\
\hline
\end{tabular}




\begin{tabular}{cccccccc}
\hline $\mathbf{1 5}$ & 54,518 & 122,833 & 410,228 & $1,663,065$ & $3,374,646$ & $5,767,255$ & $10,789,337$ \\
\hline $\mathbf{1 0}$ & 38,984 & 149,253 & 540,204 & $2,254,394$ & $3,790,746$ & $5,582,234$ & $8,965,158$ \\
\hline $\mathbf{4}$ & 162,261 & 414,621 & $1,004,010$ & $3,553,774$ & $6,350,456$ & $6,816,409$ & $8,957,465$ \\
\hline $\mathbf{1 6}$ & 0 & 85,021 & 394,833 & $1,124,265$ & $2,730,892$ & $5,610,700$ & $8,763,469$ \\
\hline $\mathbf{6}$ & 0 & 251,799 & 510,613 & $2,139,217$ & $4,634,925$ & $6,716,866$ & $8,310,219$ \\
\hline $\mathbf{1 7}$ & 5,814 & 164,409 & 493,205 & $1,147,232$ & $2,133,513$ & $5,563,926$ & $7,222,883$ \\
\hline $\mathbf{2}$ & 4,347 & 131,380 & 562,278 & $1,886,284$ & $3,330,829$ & $5,694,461$ & $6,900,639$ \\
\hline $\mathbf{5}$ & 13,103 & 236,766 & 710,161 & $2,122,373$ & $3,390,609$ & $5,404,353$ & $6,569,106$ \\
\hline $\mathbf{7}$ & 0 & 171,789 & 406,427 & $1,356,666$ & $2,968,147$ & $6,037,727$ & $6,315,285$ \\
\hline $\mathbf{9}$ & 23,047 & 44,576 & 314,930 & $1,088,747$ & $2,856,614$ & $4,069,873$ & $5,647,928$ \\
\hline $\mathbf{1}$ & 0 & 213,209 & 688,445 & $1,669,338$ & $2,749,892$ & $6,169,312$ & $5,563,077$ \\
\hline $\mathbf{1 4}$ & 0 & 13,725 & 211,468 & 676,715 & $1,621,498$ & $2,418,366$ & $4,012,151$ \\
\hline $\mathbf{1 2}$ & 0 & 87,103 & 138,557 & 571,505 & $1,408,532$ & $3,020,042$ & $3,839,533$ \\
\hline $\mathbf{2 0}$ & 245 & 30,688 & 221,688 & 802,797 & $1,218,812$ & $2,551,314$ & $3,492,541$ \\
\hline $\mathbf{1 9}$ & 8,192 & 62,916 & 167,076 & 661,022 & $1,337,245$ & $2,454,472$ & $3,485,952$ \\
\hline $\mathbf{1 3}$ & 37,818 & 90,127 & 211,724 & 609,537 & 818,245 & $1,910,055$ & $2,917,353$ \\
\hline
\end{tabular}

\section{Discussion}

As Airbnb registers booming numbers in the world, and in Paris in particular, it has

367 fuelled heated discussions and fear amongst hoteliers. Moreover, as the impact of new

368 businesses in the sharing economy, such as Airbnb, spans beyond the competitive and

369 economic aspects, it is imperative at this stage to start examining the phenomenon in more

370 depth. As such, the purpose of this research notewas not to calculate the extent of the impact

371 of Airbnb on hotel businesses in Paris but to explore the intricate relationship between the

372 Airbnb and hotel markets in Paris. We trust that it is an essential first step for future

373 complementary empirical studies. We therefore explored the monthly data as well as the

374 geographical distribution of Airbnb business across the Parisian districts. We hope that such

375 an investigation will spark discussion about the direction for future research.

In particular, while our findings confirm that the volume of activity on the Airbnb

377 platform is booming, they also show that performance results are mixed. The average

378 occupancy has reached a plateau, ADR is slightly decreasing and profitability for hosts is

379 dropping. Future research could explore the determinants of such patterns and their 
relationship, if any, with hotel's drivers of performance. In terms of the competitive threat that it can represent, our study shows different growth and seasonality patterns for Airbnb and hotels and dissimilarities in the geographical location of the offers. As Airbnb has boomed in Paris since its launch in 2009, the hotel business has also remained solid with an increase in supply and ADR. As for the seasonality patterns, they also differ for hotels and the platform as the latter manages fluctuating and seasonal supply. Finally, due to the difference in the nature of product offered, the location reflects the dissimilarities between P2P rentals and hotels. In sum, this exploration indicates that the two products are not in direct competition and that their relationship might be more complex than previously thought. We trust that exploring the nature of the competitive relationship (i.e., the impact of P2P accommodation rentals on the hotel business) would be a valuable avenue for further investigation. Although non-significant, the signs of the coefficients in the regression analyses point towards a different relationships between Airbnb and Hotel for the demand and supply sides. Future empirical investigations, could separate the demand from the supply effects of Airbnb on hotel sales performance.

Future research could, for example, investigate whether these platforms are substitutes or complements to the hotel offering. Indeed, the fact that Airbnb needs to also manage hosts' expectations and fluctuating demand reflects the specific nature of the accommodation landscape. Similarly, the annual occupancy rate of Airbnb has been far below that of hotels and its occupancy rate has been relatively stable at 50-55\% over the years. Interestingly, however, the average occupancy of hotels fluctuated between $65 \%$ and $90 \%$ over the year. July is the off season for Airbnb, whereas February is the lowest for hotels. This difference may indicate that the clientele for Airbnb is not the same as hotels. In fact, while hotels have seen their occupancy rates and bookings drop since the terror attacks in Paris, Airbnb and HomeAway-Abritel have been doing well. Travel across France fell during the summer of 
2016 in the aftershock of deadly attacks that shook Paris and Nice, even as the European soccer championship drew hundreds of thousands of fans to games held throughout the country. However, according to Airbnb, 3.6 million people stayed in an Airbnb accommodation in France between June and August 2016, which is 86 percent more than a year earlier (Weiss, 2016). Therefore, it is difficult to say that Airbnb took all business from hotels in Paris. Furthermore this finding converges with newly developed knowledge in other markets (Dogru, Mody, \& Suess, 2017).

Contrary to popular belief and despite the surge of Airbnb listings, the findings of this research paper reveal nuances in Airbnb's impact on the tourism market in Paris. In line with the notion of disruptive innovation, our exploration suggests that services such as Airbnb offer opportunities for travellers who would otherwise not have been able to travel. Therefore, the impact of Airbnb may vary across hotel markets. Also, our findings indicate that such services can benefit the tourism market as $\mathrm{P} 2 \mathrm{P}$ seasonality patterns could complement those of hotels. Further investigation into the impact of sharing accommodation platforms on overall tourism demand could explore this complementarity to find the true impact of P2P accommodation rental services on the hotel industry. 


\section{References}

Airbnb (2015, May 1). Airbnb economic impacts in France. Retrieved from http://blog.atairbnb.com/airbnb-economic-impacts-in-france/

Bryan, B. (2015, October 29). HILTON CEO: Airbnb doesn't scare us - here's why. Business Insider. Retrieved from www.businessinsider.com/hilton-ceo-airbnbcompetition-2015-10

Cheng, M. (2016). Current sharing economy media discourse in tourism. Annals of Tourism Research, 60, 111-114.

Dogru, T., Mody, M., \& Suess, C. (2017, June 7). Comparing apples and oranges? Examining the impacts of Airbnb on hotel performance in Boston. Boston Hospitality Review. Retrieved from http://www.bu.edu/bhr/2017/06/07/airbnb-in-boston/

Edelman, B, Luca, M., \& Svirsky, D (2017). Racial Discrimination in the Sharing Economy: Evidence from a Field Experiment. American Economic Journal: Applied Economics, 9(2), 1-22.

Ert, E., Fleischer, A., \& Magen, N. (2017). Trust and reputation in the sharing economy: The role of personal photos in Airbnb. Tourism Management, 55, 62-73.

Fang, B., Ye, Q., \& Law, R. (2016). Effect of sharing economy on tourism industry employment. Annals of Tourism Research, 57, 264-267.

Gibbs, C., Guttentag, D., Gretzel, U., Morton, J., \& Goodwill, A. (2017). Pricing in the sharing economy: a hedonic pricing model applied to Airbnb listings. Journal of Travel \& Tourism Marketing. http://dx.doi.org/10.1080/10548408.2017.1308292

Gutiérrez, J., García-Palomares, J. C., Romanillos, G., \& Salas-Olmedo, M. H. (2017). The eruption of Airbnb in tourist cities: Comparing spatial patterns of hotels and peer-topeer accommodation in Barcelona. Tourism Management, 62, 278-291.

Guttentag, D. (2015). Airbnb: destructive innovation and the rise of an informal tourism accommodation section in Tourism. Current Issues in Tourism, 18(12), 1192-1217.

Liang, S., Schuckert, M., Law, R., \& Chen, C. C. (2017). Be a "Superhost": The importance of badge systems for peer-to-peer rental accommodations. Tourism Management, 60, 454-465.

Lomas, N. (2016, February 5). Airbnb handed over $\$ 1.3 \mathrm{~m}$ in tourist taxes to the city of Paris in Q4 2015. TechCrunch Retrieved from https://techcrunch.com/2016/02/05/airbnb-handed-over-1-3m-in-tourist-taxes-to-thecity-of-paris-in-q4-2015/

Heo, C. Y. (2016). Sharing economy and prospects in tourism research. Annals of Tourism Research, 58(C), 166-170.

Molz, J. G. (2013). Social networking technologies and the moral economy of alternative tourism: The case of couchsurfing.org. Annals of Tourism Research. 43. 210-230.

Poon, K. Y., \& Huang, W. (2017). Past experience, traveler personality, and tripographics on intention to use AirBnB. International Journal of Contemporary Hospitality Management, https://doi.org/10.1108/IJCHM-10-2016-0599

Shaheen, S. A., Mallery, M. A., \& Kingsley, K. J. (2012). Personal vehicle sharing services in North America. Research in Transportation Business \& Management, 3, 71-81.

Tussyadiah, I. P. (2015). An exploratory study on drivers and deterrents of collaborative consumption in travel. Proceedings of the International Conference in Lugano, Switzerland, February 3-6, 2015.

Tussyadiah, I. P., \& Pesonen, J. (2016). Impacts of peer-to-peer accommodation use on travel patterns. Journal of Travel Research, 55(8) 1022-1040.

Wang, D., \& Nicolau, J. L. (2017). Price determinants of sharing economy based 
accommodation rental: A study of listings from 33 cities on Airbnb.com. International Journal of Hospitality Management, 62, 120-131.

474 Weed, J. (2015, May 11). Airbnb grows to a million rooms, and hotel rivals are quiet, for now. The New York Times. Retrieved from https://www.nytimes.com/2015/05/12/business/airbnb-grows-to-a-million-rooms-andhotel-rivals-are-quiet-for-now.html

Weiss, R. (2016, September 20). Airbnb lures France travelers while hotels lose on terrorism. Bloomberg. Retrieved from https://www.bloomberg.com/news/articles/2016-09-20/airbnb-lures-france-travelerswhile-hotels-lose-on-terror-fears

Zervas, G., Proserpio, D., \& Byers, J. W. (2017). The rise of the sharing economy: Estimating the impact of Airbnb on the hotel industry, Boston University School of Management Research Paper No. 2013-16. http://ssrn.com/abstract=2366898 